\title{
TRANSISI PERALIHAN KEWENANGAN BIDANG PENDIDIKAN SMA/SMK DI PROVINSI BANTEN
}

\author{
Fikri Habibi \\ Program Studi Administrasi Negara Universitas Serang Raya \\ Email: fikrihabibi81@gmail.com
}

\begin{abstract}
The authority of SMA / SMK, originally managed by the Regency / City Government, has been transferred to the Provincial Government. It aims to increase and equal the quality of education. In Banten Province. there are several issues related to the transfer of authority, including asset administration, both human and physical assets, as well as the ability to provide good and equitable services, and budget readiness. There are two approaches to solve it. The first approach is cluster quality and achievement, the second is cluster of educational access. Both approaches have different program priorities. Inventory and validation of personnel, facilities and infrastructure of SMA/SMK must be submitted to the Province in order to obtain certainty related to the number and needs.
\end{abstract}

Keywords: Decentralization, Transfer of Authority, and Education

\section{PENDAHULUAN}

Revisi kebijakan tentang Pemerintahan Daerah yang terkandung dalam UU Nomor 23 tahun 2014 membawa sejumlah perubahan terutama pada pembagian kewenangan antara Pusat, Provinsi dan Kabupaten/Kota. Satu di antara perubahan-perubahan yang mendapatkan sorotan adalah, adanya perpindahan kewenangan/urusan dari pemerintah kabupaten ke pemerintah provinsi begitu juga sebaliknya. Seperti yang terjadi pada kewenangan/urusan bidang pendidikan, di mana manajemen pendidikan SMA/SMK yang semula menjadi milik kabupaten/kota beralih menjadi kewenangan provinsi. Dalam lampiran UU Nomor 23 tahun 2014 dijelaskan bahwa, urusan pendidikan dengan sub urusan manajemen pendidikan telah membagi kewenangan antara pusat, provinsi, dan kabupaten/kota. Khusus tentang pengelolaan pendidikan, pembagian tersebut yaitu; Pusat mengelola pendidikan tinggi, Provinsi mengelola pendidikan menengah dan Kabupaten/Kota mengelola pendidikan dasar. Kebijakan peralihan kewenangan SMA/SMK ke provinsi sudah berlaku dan sudah harus dijalankan mulai Januari 2017.
Kebijakan peralihan kewenangan bidang SMA/SMK tersebut menuai pro dan kontra di masyarakat. Seperti yang terjadi di Kota Surabaya, di mana ribuan siswa SMA/SMK di Kota Surabaya mengirimkan surat kepada Presiden Joko Widodo agar pengelolaan urusan pendidikan menengah tidak dialihkan ke Provinsi (Sumber:https://m.tempo.co /news/2016/04/05). Mereka beranggapan, kualitas pendidikan selama ini sudah sangat baik dikelola oleh Pemkot Surabaya dan belum tentu hal tersebut terjadi ketika ditangani oleh Provinsi. Bahkan Pemkot Tangerang Selatan dan beberapa kabupaten/kota lainnya mengajukan gugatan ke Mahkamah Konstitusi sebagai upaya penolakan pengalihan kewenangan SMA/SMK ke provinsi. Ketentuan yang digugat dalam UU Nomor 23 tahun 2014 yaitu pasal 15 ayat 1 dan 2 beserta lampiran huruf A tentang Pembagian Urusan Pemerintahan Bidang Pendidikan dalam sub Urusan Manajemen Pendidikan. Pasal tersebut dinilai bertentangan dengan UUD 1945 dan memberikan kerugian konstitusional warga masyarakat. 
Akan tetapi, Mahkamah Konstitusi menolak permohonan tersebut dan menilai peralihan kewenangan SMA/SMK ke provinsi telah mempertimbangkan kriteria pemberian kewenangan urusan konkuren kepada provinsi atau kabupaten/kota atau tetap dipegang oleh pemerintah Pusat berdasarkan prinsip akuntabilitas, efisiensi, dan eksternalitas serta kepentingan strategis nasional. Menurut pendapat MK, hal tersebut tidak bertentangan dengan UUD (http://nasional.kompas.com/read/2017/07/26) . Oleh karena itu, keputusan peralihan kewenangan bidang SMA/SMK ke provinsi bersifat final dan mengikat.

Bagi pemerintah provinsi, pengalihan kewenangan bidang SMA/SMK bukannya tidak menimbulkan masalah. Setidaknya terdapat dua hal yang menjadi sorotan, yaitu soal kemampuan provinsi dalam memberikan pelayanan pendidikan berkualitas secara merata dan kemampuan anggaran. Misalnya terjadi di Sumatera Barat, di mana terdapat 9 kabupaten/kota yang sudah menyelenggarakan pendidikan gratis SMA/SMK. Ketika dialihkan ke provinsi, dikhawatirkan kebijakan tersebut tidak dilanjutkan karena kemampuan anggaran yang membebani provinsi juga bertambah. Begitu juga di Banten, seperti yang dijelaskan oleh Fitron Nur Iksan (Sekretaris Komisi V DPRD Provinsi Banten) bahwa akan ada gejolak dari para guru jika Pemprov Banten gagal melakukan antisipasi. Misalnya program yang sudah stabil di Kota Tangerang terkait program Tangerang cerdas. Pasti akan berubah perlakuan ketika sudah menjadi wewenang pengelolaannya di provinsi. Pemprov tidak akan mampu meneruskan program itu pada anggaran APBD (https://titiknol.co.id Selasa 15/11/2016 10:54 WIB).

Tugas berat pemerintah provinsi adalah memberikan standar pelayanan pendidikan yang berkualitas, atau minimal sama dengan pelayanan yang diberikan oleh kabupaten/kota sebelumnya. Tetapi secara bertahap ada langkah-langkah atau kebijakan peningkatan mutu pendidikan. Pemberian layanan pendidikan ini tentu tidak mudah karena ruang lingkup sekolah SMA/SMK yang ditangani oleh pemerintah provinsi menjadi lebih luas. Implikasi yang langsung dirasakan yaitu bertambahnya beban keuangan pemerintah provinsi dengan adanya pelimpahan kewenangan SMA/SMK. Peningkatan anggaran dalam bidang pendidikan juga disebabkan pelimpahan asetaset SMA/SMK menjadi beban provinsi (ada sekitar 1.206 sekolah). Aset-aset seperti bangunan sekolah yang dilimpahkan tidak semuanya dalam kondisi yang baik. Oleh karenanya pemeliharaan dan rehabilitasi dari gedung-gedung sekolah tersebut dibebankan kepada pemerintah provinsi. Tidak hanya itu, pembangunan unit sekolah baru beserta sarana dan prasarananya juga menjadi tanggung jawab provinsi. Kebutuhan unit sekolah baru (USB) di Provinsi Banten diperkirakan mencapai 168 unit dan 2.016 ruang kelas baru. Begitu juga dengan limpahan sumber daya manusianya seperti kepala sekolah, guru dan staf baik yang berstatus pegawai negeri sipil (PNS) maupun honorer. Limpahan SDM ini akan diikuti dengan belanja pegawai seperti pembayaran gaji, honorarium, sertifikasi serta tunjangantunjangan lainnya yang meningkat secara signifikan yang harus dialokasikan dari APBD Provinsi.

Permasalahan lain yang dihadapi Provinsi Banten dalam peralihan kewenangan SMA/SMK adalah administrasi aset baik sumber daya manusia maupun aset fisik seperti tanah dan bangunan. Ada banyak fakta bahwa aset-aset (tanah) tidak disertai dengan sertifikat kepemilikan oleh Pemda Kabupaten/Kota. Terdapat sekolah negeri (SMA/SMK) yang berada di atas tanah milik individu, pada tanah milik Pusat atau menumpang pada sekolah SD atau SMP. Hal yang sama juga terjadi pada administrasi pegawai (terutama yang berstatus honorer). Pemerintah Provinsi merasa kesulitan dengan jumlah pasti tentang data tenaga honorer yang dilimpahkan dari kabupaten/kota. Kesulitan 
inventarisasi aset ini dapat mempengaruhi kebijakan pendidikan ke depan baik soal program-program maupun masalah anggarannya.

\section{TINJAUAN TEORI}

\section{Desentralisasi dan Otonomi Daerah}

Desentralisasi dalam studi ilmu politik (Smith, 2012:1-2) merujuk pada distribusi kekuasaan berdasarkan kewilayahan (teritorial). Desentralisasi berkenaan dengan sejauh mana kekuasaan (Power) dan kewenangan (Authority) diserahkan melalui suatu hierarki secara geografis dalam negara dan juga berkenaan dengan institusi dan proses yang memungkinkan berlangsungnya pembagian tersebut. Desentralisasi mensyaratkan pembagian wilayah negara ke dalam daerah-daerah yang lebih kecil serta pembentukan institusi-institusi administratif dan politis di daerah tersebut. Pendapat hampir sama dikemukakan oleh Hoessein (Muluk, 2009:56) mengungkapkan bahwa desentralisasi mencakup dua elemen pokok. Pertama, pembentukan daerah otonom, dan kedua penyerahan urusan pemerintahan kepada daerah otonom tersebut. Dari kedua elemen pokok tersebut lalu lahirlah apa yang disebut sebagai local government

Sementara itu, Syarif Hidayat (Haris, dkk 2003:44-45) menjelaskan desentralisasi yang dibedakan dalam dua perspektif utama, yaitu desentralisasi politik dan desentralisasi administratif. Desentralisasi politik mendefinisikan desentralisasi sebagai devolution of Power, dari pemerintah pusat kepada pemerintah daerah. Sedangkan desentralisasi administratif lebih menekankan definisi desentralisasi sebagai delegasi kewenangan administratif dari pemerintah pusat kepada pemerintah daerah. Kedua bentuk desentralisasi ini biasanya memiliki penekanan tujuan yang berbeda. Desentralisasi politik lebih menekankan pada demokratisasi dan partisipasi masyarakat, sementara desentralisasi administratif lebih pada efektivitas dan efisiensi penyelenggaraan pemerintahan. Dalam praktiknya, kedua bentuk desentralisasi tersebut tidak bersifat dikotomis dan menegasikan satu sama lainnya. Meskipun ada perbedaan, mungkin hanya soal prioritasnya saja mana yang menjadi titik berat desentralisasinya.

Tujuan desentralisasi (Smith 1985, 2012), (Syaukani, Raasyid dan Gaffar, 2002:20-27), dan (Haris dkk, 2003:46-48), dapat dilihat dari dua sisi, yaitu sisi kepentingan nasional dan sisi kepentingan daerah. Dari sisi kepentingan nasional, desentralisasi memiliki sedikitnya tiga tujuan utama yaitu: (1). Political education, maksudnya adalah melalui praktik desentralisasi, diharapkan masyarakat akan belajar mengenali dan memahami berbagai persoalan sosial, ekonomi, politik yang mereka hadapi. (2). To provide training in political leadership. Melalui proses desentralisasi, pemerintah daerah merupakan wadah yang paling tepat untuk Training bagi politisi atau birokrat sebelum mereka menduduki berbagai posisi penting di tingkat nasional. Oleh karenanya, melalui kebijakan desentralisasi, diharapkan akan mampu memotivasi dan melahirkan calon-calon pimpinan pada level nasional. (3). To Create political stability. Para pendukung desentralisasi percaya bahwa desentralisasi akan mampu mewujudkan kehidupan sosial yang harmonis dan kehidupan politik yang stabil

Sedangkan dari sisi pemerintahan daerah, desentralisasi memiliki tujuan; (1). Political equality. Melalui pelaksanaan desentralisasi, diharapkan akan lebih membuka kesempatan bagi masyarakat untuk berpartisipasi dalam berbagai aktivitas politik di tingkat lokal. (2). Local accountability. Desentralisasi akan menciptakan peningkatan kemampuan pemerintah daerah dalam memperhatikan hakhak dari komunitasnya yang meliputi hak untuk ikut serta dalam proses pengambilan keputusan dan implementasi kebijakan di daerah, serta hak untuk mengontrol pelaksanaan pemerintahan daerah itu sendiri dan (3). Local reponseveness. Melalui desentralisasi, pemerintah dianggap lebih 
mengetahui berbagai masalah yang dihadapi oleh komunitasnya, maka melalui dapat menjadi jalan terbaik untuk mengatasi dan sekaligus meningkatkan akselerasi dari pembangunan sosial dan ekonomi di daerah.

\section{Pembagian Kewenangan}

Dalam desentralisasi dan otonomi daerah, hubungan antara pemerintah pusat dengan daerah sangat dipengaruhi oleh model dan besaran kewenangan yang dibagi. Pembagian kewenangan ini dapat dijadikan cara untuk mengharmonisasi hubungan pusat - daerah sehingga pemerintahan dapat berjalan dengan baik. Dalam hal ini Clarke dan Stewart (Djaenuri dan Enceng, 2011:2.11-2.12) memberikan 3 model hubungan kewenangan pemerintah pusat dan daerah. Pertama adalah model relatif, merupakan model yang dapat memberikan kebebasan pada pemerintah daerah, dan pada saat yang sama tidak mengingkari realitas negara bangsa. Penekanannya adalah dengan memberikan kebebasan bertindak pada pemerintah daerah dalam kerangka kerja kekuasaan dan kewajiban yang telah ditentukan. Hubungan pemerintah pusat dan pemerintah daerah ditentukan perundang -undangan.

Kedua, model agensi di mana pemerintah daerah berfungsi sebagai agen pelaksana kebijakan pemerintah pusat. Hal tersebut diyakini melalui spesifikasi yang terperinci dalam peraturan, perkembangan peraturan dan pengawasan. Model yang ketiga yaitu model interaksi. Merupakan model yang sulit untuk menentukan ruang lingkup kegiatan pemerintah pusat dan pemerintah daerah karena mereka terlibat hubungan yang rumit di mana penekanannya pada pengaruh yang menguntungkan saja. Pada model ini sangat sulit ditentukan tanggung jawab masingmasing otoritas karena penekanannya pada kerja sama. Dalam batas tertentu, model hubungan pemerintah pusat dan pemerintah daerah akan menghasilkan suatu partisipasi masyarakat dalam penyelenggaraan pemerintahan. Akan tetapi, jika terjadi kolaborasi antara pemerintah pusat dan daerah namun cenderung menguntungkan pemerintah pusat, maka peran masyarakat tidak sebaik pada model relatif.

Secara teoritis, persebaran urusan pemerintahan kepada daerah dapat dibedakan dalam 3 (tiga) ajaran rumah tangga berikut (Djaenuri, kenceng, dan Aisyah, 2016:4.374.30) :

a. Ajaran formal

Dalam ajaran rumah tangga formil, tidak ada perbedaan sifat urusanurusan yang diselenggarakan pemerintah pusat dan daerah otonom. Bila dilakukan pembagian tugas, hal itu semata-mata didasarkan atas pertimbangan-pertimbangan yang rasional dan praktis. Pembagian tersebut tidak karena materi yang diatur berbeda sifatnya, tetapi karena keyakinan bahwa kepentingankepentingan pemerintah daerah itu dapat lebih baik/berhasil jika dilakukan oleh pemerintah daerah daripada oleh pemerintah pusat.

b. Ajaran materiil

Dalam rumah tangga materiil, antara pemerintah pusat dan daerah terdapat pembagian tugas yang terperinci secara tegas di dalam peraturan perundang-undangan. Kewenangan setiap daerah hanya meliputi tugastugas yang ditentukan satu per satu secara normatif.

c. Ajaran riil

Sistem ini merupakan upaya jalan tengah antara ajaran rumah tangga formil dan materiil dengan tidak melepaskan prinsip sistem rumah tangga formil. Konsep rumah tangga riil bertitik tolak dari pemikiran yang mendasarkan diri kepada keadaan dan faktor-faktor nyata untuk mencapai keserasian antara tugas dan kemampuan dan kekuatan baik yang ada pada daerah sendiri maupun pusat. Dalam ajaran rumah tangga riil, dianut sebuah kebijaksanaan bahwa setiap undang-undang pembentukan daerah 
mencantumkan beberapa urusan rumah tangga daerah yang dinyatakan sebagai modal pangkal dengan disertai segala atributnya berupa kewenangan, personil, alat perlengkapan dan sumber pembiayaan. Urusan-urusan pemerintahan dapat ditambahkan dalam perjalanannya sesuai dengan kesanggupan dan kemampuan daerah yang bersangkutan.

Sementara Wolman (Gadjong, 2007:95) memberikan 2 kriteria yang dapat digunakan dalam pembagian urusan. Kriteria yang pertama yaitu aspek efisiensi (efficiency value), meliputi ada atau tidaknya manfaat dari skala ekonomi, ada tidaknya eksternalitas, baik positif maupun negatif, disparitas ekonomi dan kapasitas administrasi, variasi preferensi masyarakat terhadap public goods, serta pemeliharaan stabilitas ekonomi makro. Kriteria yang kedua adalah aspek pengelolaan pemerintahan, meliputi kepekaan dan akuntabilitas, kemajemukan sosial budaya, serta partisipasi publik. Leach dan Davis berpendapat bahwa, dalam melakukan pembagian urusan pemerintahan harus mengacu pada tujuan dan peran pemerintahan daerah karena hal ini akan mempengaruhi rancangan pembagian. Terdapat tiga dimensi pilihan strategis dalam menetapkan tujuan dan peran pemerintah daerah di masa yang akan datang, yaitu (1). Dimensi kepemerintahan, (2). Pasar (market), (3). Komunitas. Jadi, pada dasarnya urusan-urusan pemerintahan yang diserahkan atau dilimpahkan kepada pemerintah daerah tentunya memerlukan/membutuhkan suatu kewenangan atau kekuasaan untuk melaksanakannya.

Dalam perjalanan pembagian kewenangan/urusan antara pemerintah pusat dan daerah yang diatur dalam undang-undang tentang pemerintahan daerah memiliki perbedaan. Dalam UU Nomor 22 tahun 1999 misalnya, kewenangan/urusan yang dibagi dilakukan prinsip residual function. Prinsip ini dilaksanakan dengan membagi terlebih dahulu kewenangan-kewenangan yang menjadi milik pemerintah pusat, dan sisanya menjadi kewenangan pemerintah daerah. Akan tetapi, prinsip tersebut kemudian berubah dalam UU Nomor 32 tahun 2004 dan UU Nomor 23 tahun 2014 yang menggunakan prinsip concurrent function termasuk perubahan istilah wewenang/kewenangan menjadi urusan.

Urusan pemerintah yang bersifat concurrent (Abdullah, 2005:17) yaitu urusan pemerintahan yang penanganannya dalam bagian atau bidang tertentu, dapat dilaksanakan bersama antara pemerintah pusat dan pemerintah daerah. Prinsip ini membagi kewenangan dengan ketentuan bahwa bidang yang dikerjakan oleh pemerintah pusat, provinsi, kabupaten/kota adalah sama. Perbedaannya terletak pada ruang lingkup urusan yang ditanganinya saja. Akan tetapi hal tersebut tidak berlaku bagi kewenangankewenangan absolut yang dimiliki oleh pusat yang tidak dibagi ke pemerintahan daerah. Sementara itu, soal perubahan wewenang menjadi urusan, Bhenyamin Hoessein (Wignosubroto, 2005:203-204) menilai bahwa pemakaian istilah urusan lebih baik daripada kewenangan dengan berbagai pertimbangan. Konsep urusan pemerintahan menunjukkan dua indikator penting, yaitu fungsi atau aktivitas dan asal urusan pemerintahan tersebut. urusan pemerintahan yang didistribusikan hanya berasal dari Presiden dan tidak berasal dari organ-organ (lembaga-lembaga) negara lainnya. Oleh karena itu, dalam konteks ini muncul berbagai urusan pemerintahan seperti pendidikan, kesehatan, pekerjaan umum dan lain-lain.

Penentuan ruang lingkup masing-masing urusan tersebut (urusan konkuren), dalam kebijakan pemerintahan daerah di Indonesia menggunakan kriteria yaitu eksternalitas, efisiensi, akuntabilitas dan kepentingan strategis nasional (Pasal 13 UU Nomor 23 tahun 2014 ayat 1). Dalam penjelasan pasal tersebut yang dimaksud dengan "prinsip akuntabilitas" adalah penanggung jawab penyelenggaraan suatu urusan pemerintahan ditentukan berdasarkan kedekatannya dengan 
luas, besaran, dan jangkauan dampak yang ditimbulkan oleh penyelenggaraan suatu urusan pemerintahan. Prinsip efisiensi adalah penyelenggara suatu urusan pemerintahan ditentukan berdasarkan perbandingan tingkat daya guna yang paling tinggi yang dapat diperoleh.

Sementara itu prinsip eksternalitas adalah penyelenggara suatu urusan pemerintahan ditentukan berdasarkan luas, besaran, dan jangkauan dampak yang timbul akibat penyelenggaraan suatu urusan pemerintahan. Dan yang terakhir yaitu prinsip kepentingan strategis nasional dalam ketentuan ini adalah penyelenggara suatu urusan pemerintahan ditentukan berdasarkan pertimbangan dalam rangka menjaga keutuhan dan kesatuan bangsa, menjaga kedaulatan Negara, implementasi hubungan luar negeri, pencapaian program strategis nasional dan pertimbangan lain yang diatur dalam ketentuan peraturan perundangundangan. Selanjutnya pada pasal 13 ayat 2-4 dijelaskan bahwa yang menjadi kewenangan Pemerintah Pusat yaitu:
a. Urusan Pemerintahan yang lokasinya lintas Daerah provinsi atau lintas negara;
b. Urusan Pemerintahan yang penggunanya lintas Daerah provinsi atau lintas negara;
c. Urusan Pemerintahan yang manfaat atau dampak negatifnya lintas Daerah provinsi atau lintas negara;
d. Urusan Pemerintahan yang penggunaan sumber dayanya lebih efisien apabila dilakukan oleh Pemerintah Pusat; dan/atau
e. Urusan Pemerintahan yang peranannya strategis bagi kepentingan nasional.

Sementara kewenangan pemerintah provinsi berkaitan dengan (a). Urusan Pemerintahan yang lokasinya lintas Daerah kabupaten/kota; (b).Urusan Pemerintahan yang penggunanya lintas Daerah kabupaten/kota; (c). Urusan Pemerintahan yang manfaat atau dampak negatifnya lintas Daerah kabupaten/kota; dan/atau, (d). Urusan Pemerintahan yang penggunaan sumber dayanya lebih efisien apabila dilakukan oleh Daerah Provinsi. Sementara kewenangan kabupaten/kota meliputi:
a. Urusan Pemerintahan yang lokasinya dalam Daerah kabupaten/kota;
b. Urusan Pemerintahan yang penggunanya dalam Daerah kabupaten/kota;
c. Urusan Pemerintahan yang manfaat atau dampak negatifnya hanya dalam Daerah kabupaten/kota; dan/atau penggunaan sumber dayanya lebih efisien apabila dilakukan oleh Daerah kabupaten/kota.
d. Urusan Pemerintahan yang

\section{METODE PENELITIAN}

Penelitian ini menggunakan metode deskriptif dengan pendekatan kualitatif. Datadata yang digunakan dalam penelitian ini bersumber dari data primer dan data sekunder. Data primer didapatkan melalui wawancara dengan informan yang memiliki kompetensi untuk menjawab permasalahan penelitian. Sementara data sekunder bersumber dari dokumen, laporan, dan berita di media massa.

\section{PEMBAHASAN}

Seperti yang dijelaskan sebelumnya bahwa upaya efektivitas dan efisiensi penyelenggaraan pemerintahan antara pusatdaerah, salah satunya menggunakan instrumen pembagian kewenangan. Tidak hanya itu, pembagian kewenangan yang seimbang ini akan membawa harmonisasi hubungan antara pemerintah pusat dan daerah. Jika ada dinamika pembagian kewenangan seperti peralihan kewenangan dari pusat ke daerah, begitu juga sebaliknya atau antar pemerintahan daerah (provinsikabupaten/kota) semata-mata ditujukan demi melayani masyarakat yang lebih baik. Hal 
tersebut juga berlaku dalam kewenangan SMA/SMK yang dialihkan ke pemerintah provinsi di mana sebelumnya menjadi kewenangan kabupaten/kota. Maksud dan tujuan peralihan tersebut dapat kita lihat dari dua hal yaitu pemerataan kualitas pendidikan (khususnya peningkatan wajib belajar 12 tahun) dan manajemen pengelolaan pendidikan yang lebih terfokus termasuk penggunaan anggaran pendidikan pada masing-masing pemerintahan.

Kemampuan masing-masing daerah Kabupaten/Kota dalam memberikan kualitas pelayanan pendidikan sangat beragam. Oleh karena itu, munculnya disparitas kualitas pendidikan terjadi di Kabupaten dan Kota meskipun dalam satu Provinsi. Terdapat Kabupaten dan Kota yang sudah mampu menyelenggarakan pendidikan gratis dan berkualitas sampai tingkat SMA/SMK (seperti Kota Cilegon, Kota Tangerang), sementara di sisi yang lain ada pemerintah daerah yang mengalami kesulitan meskipun hanya untuk mengejar wajib belajar 9 tahun. Sehingga peningkatan wajib belajar menjadi 12 tahun sulit tercapai mengingat kemampuan Kabupaten/Kota yang timpang. Oleh karena itu, peningkatan wajib belajar tersebut dirasa akan lebih efektif jika diserahkan kepada Pemerintah Provinsi. Dengan demikian, peningkatan kualitas pendidikan dapat dilakukan secara merata di Kabupaten dan Kota.

Peralihan kewenangan SMA/SMK ke provinsi menjadikan pengelolaan/manajemen pendidikan menjadi lebih terfokus berdasarkan jenjang pendidikan. Sebelumnya, kabupaten dan kota menanggung beban yang sangat berat yaitu bertanggung jawab atas pelayanan pendidikan dasar dan menengah. Pada lampiran UU Nomor 23 tahun 2014 dalam hal Pembagian Urusan Pemerintahan Konkuren antara Pemerintah Pusat dan daerah Provinsi dan Daerah Kabupaten/Kota dalam urusan pemerintahan bidang pendidikan disebutkan sebagai berikut:
Tabel. 2.1

\section{Pembagian Urusan Bidang Pendidikan}

\begin{tabular}{|c|c|c|c|c|}
\hline No & $\begin{array}{c}\text { Sub } \\
\text { Urusan }\end{array}$ & $\begin{array}{c}\text { Pemerintah } \\
\text { Pusat }\end{array}$ & $\begin{array}{l}\text { Daerah } \\
\text { Provinsi }\end{array}$ & $\begin{array}{c}\text { Daerah } \\
\text { Kabupaten/ } \\
\text { Kota }\end{array}$ \\
\hline 1 & $\begin{array}{l}\text { Manaje } \\
\text { men } \\
\text { Pendidi } \\
\text { kan }\end{array}$ & $\begin{array}{l}\text { Penetapan } \\
\text { standar } \\
\text { nasional } \\
\text { pendidikan } \\
\text { Pengelolaan } \\
\text { pendidikan } \\
\text { tinggi }\end{array}$ & $\begin{array}{l}\text { Pengelola } \\
\text { an } \\
\text { pendidika } \\
\mathrm{n} \\
\text { menengah } \\
\text { Pengelola } \\
\text { an } \\
\text { pendidika } \\
\mathrm{n} \text { khusus }\end{array}$ & $\begin{array}{l}\text { Pengelolaan } \\
\text { pendidikan } \\
\text { dasar, } \\
\text { Pengelolaan } \\
\text { pendidikan } \\
\text { anak usia } \\
\text { dini dan } \\
\text { pendidikan } \\
\text { non formal }\end{array}$ \\
\hline
\end{tabular}

Tabel di atas menunjukkan bahwa, masing-masing pemerintahan (Pusat-ProvinsiKabupaten/Kota) memiliki pengelolaan jenjang pendidikan yang berbeda. Setiap jenjang pendidikan dikelola oleh jenjang pemerintahan yang berbeda. Peralihan kewenangan SMA/SMK juga akan mengurangi beban anggaran APBD Kabupaten/Kota sekaligus lebih mengoptimalkan anggaran pendidikan di APBD Provinsi untuk SMA/SMK. Anggaran yang sebelumnya diperuntukkan pada SMA/SMK pada APBD Kabupaten/Kota dapat dialihkan guna peningkatan kualitas pendidikan dasar, usia dini dan non formal.

Lazimnya dalam sebuah kebijakan, peralihan kewenangan SMA/SMK ke Provinsi tentunya menimbulkan beberapa permasalahan termasuk di Provinsi Banten. Ada beberapa hal yang menjadi perhatian Pemprov Banten sebagai konsekuensi dari peralihan kewenangan tersebut.

\section{Pemerataan kualitas pendidikan}

Seperti yang sudah dijelaskan sebelumnya, bahwa ada disparitas kualitas pendidikan khususnya tingkat SMA/SMK di Provinsi Banten. Angka Partisipasi Kasar (APK) dan Angka Partisipasi Murni (APM) pada tingkat SMA/SMK masih rendah. Hal tersebut dapat dilihat pada tabel di bawah ini: 
Tabel.2.2

\begin{tabular}{|c|c|c|c|c|c|c|}
\hline APK dan & M Men & $\mathbf{T i}$ & t pen & lika & $10 \mathrm{~V}$ & nten \\
\hline $\begin{array}{l}\text { Tingkat } \\
\text { Pendidika }\end{array}$ & $\begin{array}{r}\text { Angka } \\
(A P K) \\
P\end{array}$ & $\begin{array}{l}\text { rtisipas } \\
\text { nurut } \\
\text { didika }\end{array}$ & $\begin{array}{l}\text { Kasar } \\
\text { ingkat }\end{array}$ & $\begin{array}{l}\text { Ang } \\
\text { (AP }\end{array}$ & $\begin{array}{l}\text { Partisi } \\
\text { Menu } \\
\text { Pendid }\end{array}$ & $\begin{array}{l}\text { Murni } \\
\text { ingkat }\end{array}$ \\
\hline & 2013 & 2014 & 2015 & 2013 & 2014 & 2015 \\
\hline SD/MI & 107.47 & $\begin{array}{c}109.8 \\
9\end{array}$ & $\begin{array}{c}112.0 \\
7\end{array}$ & 96.24 & 96.69 & 96.98 \\
\hline $\begin{array}{l}\text { SMP/MT } \\
\text { s }\end{array}$ & 89.85 & 89.55 & 92.30 & 78.17 & 79.56 & 79.87 \\
\hline SMA/MA & 63.32 & 72.94 & 69.73 & 53.28 & 56.87 & 57.04 \\
\hline
\end{tabular}

Sumber:

htps://banten.bps.go.id

Sementara Angka Partisipasi Sekolah (APS) berdasarkan kelompok umur pada setiap Kabupaten dan Kota di Provinsi Banten yaitu:

Tabel. 2.3

APS Menurut Kabupaten/Kota dan Kelompok Umur di Provinsi Banten (\%)

\begin{tabular}{|l|c|c|c|c|c|c|c|c|c|c|c|c|c|c|c|}
\hline \multicolumn{8}{|c|}{ Angka Partisipasi Sekolah (APS) Menurut Kabupaten/Kota dan Kelompok Umur } \\
\hline \multirow{2}{*}{ Kabupaten/Kota } & \multicolumn{3}{|c|}{$\mathbf{0 7 - 1 2}$} & \multicolumn{3}{|c|}{$\mathbf{1 3 - 1 5}$} & \multicolumn{3}{|c|}{$\mathbf{1 6}$} & \multicolumn{3}{|c|}{} \\
\cline { 2 - 13 } & $\mathbf{2 0 1 1}$ & $\mathbf{2 0 1 2}$ & $\mathbf{2 0 1 3}$ & $\mathbf{2 0 1 4}$ & $\mathbf{2 0 1 1}$ & $\mathbf{2 0 1 2}$ & $\mathbf{2 0 1 3}$ & $\mathbf{2 0 1 4}$ & $\mathbf{2 0 1 1}$ & $\mathbf{2 0 1 2}$ & $\mathbf{2 0 1 3}$ & $\mathbf{2 0 1 4}$ \\
\hline Kab Pandeglang & 98.17 & 97.6 & 98.03 & 97.48 & 86.71 & 91.69 & 90.14 & 91.32 & 56.49 & 53.29 & 55.99 & 63.47 \\
\hline Kab Lebak & 96.53 & 97.40 & 97.64 & 99.46 & 83.76 & 84.49 & 85.83 & 92.71 & 41.25 & 44.09 & 55.58 & 58.32 \\
\hline Kab Tangerang & 98.66 & 98.62 & 98.75 & 99.47 & 88.41 & 91.53 & 91.27 & 94.69 & 48.88 & 58.26 & 62.31 & 64.37 \\
\hline Kab Serang & 97.37 & 98.93 & 98.96 & 99.89 & 86.35 & 91.01 & 90.84 & 95.36 & 54.24 & 51.14 & 58.25 & 64.92 \\
\hline Kota Tangerang & 98.95 & 97.81 & 99.05 & 99.60 & 93.58 & 94.69 & 93.34 & 98.21 & 64.46 & 69.55 & 68 & 70.17 \\
\hline Kota Cilegon & 98.83 & 98.84 & 99.79 & 99.60 & 90.49 & 96.76 & 97.39 & 98.03 & 66.67 & 68.40 & 72.63 & 78.19 \\
\hline Kota Serang & 96.85 & 97.05 & 97.54 & 99.16 & 81.44 & 86.87 & 85.47 & 93.22 & 56.20 & 58.54 & 62.95 & 67.09 \\
\hline $\begin{array}{l}\text { Kota Tangerang } \\
\text { Selatan }\end{array}$ & 99.79 & 99.61 & 99.16 & 99.47 & 95.13 & 93.58 & 94.79 & 96.32 & 73.18 & 68.85 & 69.18 & 74.72 \\
\hline Provinsi Banten & 98.23 & 98.29 & 98.60 & 99.29 & 88.36 & 90.97 & 90.90 & 94.87 & 56.16 & 58.58 & 62.31 & 66.25 \\
\hline
\end{tabular}

Sumber: htps://banten.bps.go.id

Data di atas menunjukkan bahwa angka partisipasi dan pemerataan pendidikan pada jenjang SMA/SMK di Provinsi Banten masih rendah. Fakta ini menjadi pekerjaan yang sangat berat bagi Pemprov Banten dalam upaya peningkatan dan pemerataan pendidikan tingkat SMA/SMK. Fakta lainnya yaitu, selain secara agregat angka partisipasi SMA/SMK masih rendah, juga adanya keragaman tingkat partisipasi dari masing- masing Kabupaten/Kota. Hal tersebut dapat menyulitkan Pemprov Banten dalam melakukan standar mutu pada masing-masing sekolah di daerah kabupaten/kota. Oleh karena itu, harus ada perlakuan/kebijakan/pendekatan yang berbeda pada masing-masing daerah kabupaten/kota dalam upaya peningkatan kualitas pendidikan.

Peningkatan kualitas pendidikan sangat berkaitan dengan penyediaan sarana dan pra 
sarana (gedung sekolah, laboratorium, perpustakaan, sarana pengembangan minat dan bakat dll), kualitas tenaga pengajar dan kemudahan akses bagi masyarakat. Kondisi sarana dan prasarana pendidikan di Banten, data menunjukkan bahwa persentase sekolah tingkat SMA yang memiliki perpustakaan yaitu 64\%, sementara SMK hanya 47\% saja. Keadaan yang kurang baik terjadi pada SMK, di mana hanya $32 \%$ saja yang memiliki laboratorium. Data yang hampir sama juga terjadi dengan kondisi ruang kelas SMA dan SMK di Provinsi Banten:

Tabel. 2.4

\section{Kondisi Ruang Kelas SMA/SMK Provinsi} Banten 2016

\begin{tabular}{|c|l|c|c|}
\hline No & $\begin{array}{c}\text { Kondisi } \\
\text { Ruang } \\
\text { Kelas }\end{array}$ & SMA & SMK \\
\hline 1 & Baik & 2.638 & 2.450 \\
\hline 2 & $\begin{array}{l}\text { Rusak } \\
\text { Ringan }\end{array}$ & 2.072 & 3.102 \\
\hline 3 & Rusak Berat & 131 & 121 \\
\hline
\end{tabular}

Sumber: Neraca pendidikan Provinsi Banten 2016

Dibutuhkan sebuah kebijakan (program dan anggaran) yang mampu mengakselerasi peningkatan dan pemerataan mutu pendidikan di Banten. Guna peningkatan pelayanan pendidikan yang baik, dapat digunakan dua pendekatan yang didasarkan pada klasterisasi sekolah. Pertama, cluster pendekatan mutu dan prestasi. Pendekatan ini ditujukan kepada sekolah-sekolah yang sejak awal memiliki kualitas yang baik. Kualitas tersebut didasarkan pada akreditasi sekolah, sarana, mutu pembelajaran, kualifikasi/tingkat pendidikan guru dan lain sebagainya. Kebijakan yang diambil untuk sekolahsekolah pada grade ini adalah mempertahankan mutu yang sudah ada (target minimal) dan secara bertahap dilakukan peningkatan level mutu dan prestasi. Target yang harus dipenuhi pada sekolah-sekolah tersebut, misalnya mampu bersaing di tingkat nasional, regional dan internasional berdasarkan visi Pemprov Banten.
Kedua, cluster pendekatan akses pendidikan. Diperuntukkan bagi sekolahsekolah yang masih belum memenuhi standar pelayanan pendidikan yang memadai. Oleh karena itu, program prioritasnya adalah memenuhi infrastruktur/sarana dan pra sarana sekolah, pembangunan unit sekolah baru, penambahan dan perbaikan ruang kelas, penyediaan laboratorium serta pemenuhan rasio guru dan murid. Data-data di atas menunjukkan bahwa seharusnya prioritas program-program bidang pendidikan diarahkan pada pembangunan infrastruktur pendidikan sehingga memenuhi standar yang baik. Selain itu, program-program pembangunan sarana dan prasarana pendidikan juga dapat lebih menyasar wilayah perdesaan agar akses masyarakat terhadap pendidikan SMA/SMK dapat meningkat secara signifikan. Data BPS 2015 menunjukkan bahwa, APS pada kelompok umur 16-18 tahun (SMA/SMK) di perkotaan mencapai $73 \%$, sementara di perdesaan hanya 54\%. Masih sangat lebar disparitas pendidikan antara perdesaan dengan wilayah perkotaan. Alternatif lain yang dapat dilakukan guna peningkatan akses pendidikan yaitu membuka SMA/SMK terbuka negeri khususnya di wilayah-wilayah perdesaan. Melalui prioritas pembangunan akses pendidikan, disparitas wilayah perdesaan dan perkotaan akan mampu diperpendek.

Meskipun prioritasnya pada infrastruktur dan akses pendidikan, langkah ini tetap diikuti dengan peningkatan mutu dan prestasi sekolah guna mengejar sekolah-sekolah yang sudah lebih dahulu memenuhi standar. Indikator yang paling sederhana tentang kualitas pendidikan dapat dilihat pada akreditasi sekolah. 
Tabel. 2.5

Akreditasi SMA/SMK di Provinsi Banten

\begin{tabular}{|c|c|c|}
\hline AKREDITASI & SMA & SMK \\
\hline A & $26.2 \%$ & $28.3 \%$ \\
\hline B & $29.6 \%$ & $50.2 \%$ \\
\hline C & $12.9 \%$ & $21.5 \%$ \\
\hline $\begin{array}{c}\text { Tidak } \\
\text { Terakreditasi }\end{array}$ & $31.4 \%$ & - \\
\hline
\end{tabular}

Banten 2016

Sumber: Neraca Pendidikan

Targetnya, 2-3 tahun kedua pendekatan di atas dapat bertemu pada titik yang sama dan menunjukkan terjadinya peningkatan sekaligus pemerataan mutu dan prestasi sekolah di Banten. Misalnya, sudah tidak ada lagi sekolah yang memiliki akreditasi C bahkan belum tidak terakreditasi. Sekolahsekolah SMA/SMK di Banten, minimal mendapatkan akreditasi B dan secara bertahap menuju akreditasi A.

\section{Penataan sumber daya manusia dan aset fisik}

Pemerintah Provinsi Banten akan menampung limpahan SDM seperti guru dan staf baik yang berstatus PNS maupun honorer sebagai konsekuensi perlahan kewenangan SMA/SMK. Jumlah pegawai yang dilimpahkan sekitar 15.119 guru baik PNS maupun honorer serta 3.279 pegawai/staf. Pelimpahan tersebut akan berdampak pada peningkatan belanja pegawai pada APBD Provinsi Banten. Hal lain yang menjadi persoalan di samping peningkatan beban APBD Provinsi, yaitu soal administrasi kepegawaian khususnya yang berstatus honorer.

Banyak guru dan staf honorer yang akan dilimpahkan ke Pemprov Banten hanya bermodalkan SK Kepala Sekolah ketika dilakukan pengangkatan. Implikasinya, Pemprov Banten merasa kesulitan dalam menentukan jumlah riil kebutuhan tenaga honorer tersebut. Hal tersebut dapat menimbulkan situasi yang dilematis bagi Pemprov Banten. Satu sisi, peralihan kewenangan SMA/SMK ke provinsi juga diikuti dengan peralihan sumber daya manusia, akan tetapi di sisi lain jumlah tenaga honorer yang akan dilimpahkan tidak disertai dengan rasio kebutuhan yang akurat. Dampaknya, Pemprov Banten dapat saja menerima tenaga pendidik dan staf honorer tersebut jauh melebihi kebutuhan di Provinsi Banten dan pastinya berimbas pada beban APBD.

Permasalahan yang sama juga terjadi pada aset-aset seperti bangunan dan tanah yang diserahkan kepada Pemprov Banten. Faktanya, masih banyak aset-aset yang tersebut yang memiliki permasalahan, mulai dari pencatatan, kepemilikan dan lain sebagainya. Seperti yang telah dikemukakan sebelumnya, bahwa ada sekolah-sekolah negeri (SMA/SMK) yang berada di atas tanah dengan status tanah milik pribadi bukan pemerintah. Kasus lainnya, tanah-tanah ada yang hanya memiliki dokumen akta jual beli (AJB) dan sekolah-sekolah yang dibangun di atas tanah pemerintah pusat.

Pemprov Banten sudah membuat tim verifikasi guna inventarisasi personel, sarana dan prasarana dan dokumen (P3D). Pemprov juga melakukan validasi baik dokumen maupun verifikasi lapangan untuk memastikan jumlah dan status aset baik SDM maupun fisik (bangunan dan tanah) karena akan mempengaruhi kebijakan ke depan. Misalnya soal SDM yang berstatus honorer, setelah lolos verifikasi dan validasi, kemudian akan dibuatkan SK baru pengangkatan yang ditandatangani minimal oleh eselon 1 Pemprov.

Tunjangan-tunjangan yang diberikan baik kepada kepala sekolah, guru, dan staf dibuat flat di seluruh wilayah kabupaten dan kota. Namun, ke depan, tunjangan-tunjangan tersebut juga dapat menyesuaikan dengan variabel lain misalnya UMK masing-masing kabupaten/kota. Variabel lainnya yaitu tunjangan guru/kepala sekolah/staf untuk daerah-daerah terpencil di Provinsi Banten. Langkah ini dapat dijadikan salah satu solusi dalam upaya pemerataan guru-guru sekaligus pemerataan kualitas pendidikan. Tunjangan daerah terpencil ini juga dapat berfungsi 
sebagai stimulan dalam proses mutasi pegawai.

Langkah serupa dapat dilakukan pada aset fisik, verifikasi dan validasi aset-aset tersebut dilakukan dengan baik dan hati-hati. Setelah dilakukan inventarisasi baik jumlah aset maupun masalah-masalahnya, Pemprov Banten dapat menyelesaikan persoalan aset tersebut secara bertahap. Prioritasnya pada aset-aset yang masih dimiliki sertifikatnya oleh individu, AJB bahkan tidak ada dokumen sama sekali. Aset-aset ini harus segera dibebaskan meskipun akan membebani APBD Provinsi Banten. Akhir tahun 2017 ini merupakan target dari Provinsi Banten untuk menuntaskan persoalan administrasi terkait inventarisasi, verifikasi dan validasi sumber daya manusia dan aset fisik.

Kesiapan anggaran Pemprov Banten dan provinsi-provinsi lainnya menjadi salah hal yang mendapatkan perhatian dalam menghadapi konsekuensi peralihan tersebut. Pasti ada peningkatan anggaran sektor pendidikan, di Provinsi Banten pada APBD 2017 dialokasikan sebesar $438 \mathrm{M}$ atau 12\% dari APBD. Persentasi tersebut dianggap masih kecil, namun dapat ditingkatkan pada setiap tahun anggarannya. Belum lagi ada tambahan bantuan keuangan dari pemerintah Pusat melalui BOS yang dapat membantu peningkatan dan pemerataan kualitas pendidikan. Tahun 2017, anggaran urusan pendidikan dalam APBD Banten termasuk belanja hibah (hibah BOS, Institusi Pendidikan), belanja bagi hasil Kabupaten/Kota, belanja bantuan keuangan, dan belanja langsung fungsi pendidikan mencapai $3.19 \mathrm{~T}$ atau $30.13 \%$. Angka tersebut sudah cukup besar dan mampu menghadapi konsekuensi peralihan kewenangan SMA/SMK dari sisi anggaran. Belanja hibah yang dahulu ditransfer ke kabupaten/kota untuk pendidikan (SMA/SMK), tinggal dialihkan saja menjadi belanja modal misalnya. Dukungan pada program pendidikan dapat dilakukan melalui program efisiensi pada masing-masing SKPD. Misalnya, penghapusan honorarium jika pekerjaan tersebut sesuai dengan tugas dan fungsinya, atau mengurangi rapat-rapat di luar kantor (hotel) dan dialihkan untuk sektor pendidikan.

\section{KESIMPULAN}

Peralihan kewenangan SMA/SMK ke Pemerintah Daerah Provinsi diharapkan mampu mewujudkan peningkatan dan pemerataan pendidikan. Permasalahan terkait dengan anggaran, administrasi aset fisik maupun non fisik (sumber daya manusia). Tantangan lainnya yaitu kemampuan untuk memberikan kualitas pendidikan yang baik jauh melebihi pelayanan pendidikan yang diberikan sebelumnya oleh kabupaten/kota. Kita juga berharap, ketika SMA/SMK diserahkan pada pemerintah provinsi, ketimpangan pendidikan yang sebelumnya terjadi dapat terus diminimalkan.

Beberapa langkah dapat dilakukan oleh Pemprov Banten, pertama, rasionalisasi sumber daya manusia yang berasal dari limpahan pegawai kabupaten/kota baik jumlah maupun sebaran wilayahnya. Guru dan staf (khususnya honorer) yang terkena rasionalisasi dapat ditempatkan di sekolahsekolah baru yang akan dibangun. Kedua, akselerasi pembangunan infrastruktur pendidikan pada wilayah-wilayah selatan Banten (Lebak dan Pandeglang). Ketiga, program pelayanan pendidikan gratis dapat terus dipertahankan dan dilaksanakan secara merata pada SMA/SMK negeri di seluruh Provinsi Banten. 


\section{DAFTAR PUSTAKA}

Abdullah, Rozali, (2005), Pelaksanaan Otonomi Luas dengan Pemilihan Kepala Daerah Secara Langsung, PT. RajaGrafindo Persada, Jakarta

Djaenuri, Aries dan Enceng (2011), "Sistem Pemerintahan Daerah" Universitas Terbuka, Jakarta

Djaenuri, Aries, Enceng dan Siti Aisyah (2016), "Sistem Pemerintahan Daerah" Cetakan Kedua Belas, Universitas Terbuka, Jakarta

Gadjong, Agussalim Andi, (2007), Pemerintahan Daerah; Kajian Politik dan Hukum, PT. Ghalia Indonesia, Bogor

Haris, Syamsuddin. Dkk, (2003), Desentralisasi dan Otonomi Daerah; Naskah Akademik dan RUU Usulan LIPI, Pusat Penelitian Politik-LIPI bekerja sama dengan Partnership for Governance Reform in Indonesia (PGRI), Jakarta

Hoessein, Bhenyamin, (2009), Perubahan Model, Pola dan Bentuk Pemerintahan Daerah; Dari Era Orde Baru ke Era Reformasi, Departemen Ilmu Administrasi FISIP Universitas Indonesia, Jakarta

http://dindik.bantenprov.go.id/v3/index.php/d apo/rekap.html

https://titiknol.co.id/pemerintahan/peralihankewenangan-sma-smk-dinilai-akanbergejolak/ Selasa 15/11/2016

http://nasional.kompas.com/read/2017/07/26/ 20291101/mk-kukuhkan-pengelolaansma-smk-merupakan-kewenanganpemprov

https://banten.bps.go.id/

https://m.tempo.co/read/news/2016/04/05/079 759769/polemik-alih-pengelolaansma-smk-ini-komentar-menteri-anies
Muluk, M.R. Khairul, (2009), Peta Konsep Desentralisasi dan Pemerintahan Daerah, ITS Press Surabaya bekerjasama dengan Lembaga Penerbitan dan Dokumentasi FIA Universitas Brawijaya Malang

Muthalib, M.A dan Mohd. Akbar Ali Khan. (1983), Theory of Local Government (Teori Pemerintahan Daerah), Terjemahan Cetakan Pertama 2013, Masyarakat Ilmu Pemerintahan Indonesia (MIPI), Jakarta

Smith, Brian C, (1985), Desentralisasi; Dimensi Teritorial Suatu Negara, Edisi Terjemahan Cetakan Pertama 2012, Masyarakat Ilmu pemerintahan Indonesia (MIPI), Jakarta

Syaukani, HR, Afan Gaffar dan M. Ryaas Rayid, (2002), Otonomi Daerah Dalam Negara Kesatuan, Pustaka Pelajar, Yogyakarta

Undang-Undang Nomor 23 tahun 2014 tentang Pemerintahan Daerah

Wahidin, Samsul, (2013), Hukum Pemerintahan Daerah, Pendulum Otonomi Daerah dari Masa ke Masa, Pustaka Pelajar, Yogyakarta

Wignosubroto, Soetandyo dkk, (2005), Pasang Surut Otonomi Daerah; Sketsa Perjalanan 100 tahun, Institute for Local Development-Yayasan Tifa, Jakarta 